\title{
Acute Infective Bloody Diarrhea in Children Below Five Years Admitted to Children Welfare Hospital in Medical City - Baghdad During 2015
}

\author{
Maral F. Thabit ${ }^{1}$, Radhwan R Hussian ${ }^{2}$ \\ ${ }^{1}$ Institute of Medical Technology,Baghdad/Head of Physiotherapy department, ${ }^{2}$ Baghdad Teaching Hospital
}

\begin{abstract}
Bloody diarrhea in young children is usually a sign of invasive enteric infection that carry a substantial risk of serious morbidity and death. Objectives : to identify the proportion of infective bloody diarrhea out of total number of gastro-enteritis cases, also to identify the prevalence of different etiological agents and to find the relation between the main infective etiological types of bloody diarrhea and some sociodemographic factors of this study. Retrospective study was conducted in Children Welfare Teaching Hospital / Baghdad during period extending from $1{ }^{\text {st }}$ of January to $30^{\text {th }}$ of June 2016. Information was collected by reviewing the records of patients with acute infective bloody diarrhea under 5 years of age admitted during 2015. The study revealed that the proportion of infective bloody diarrhea was $10.9 \%$ out of the total gastroenteritis (788) cases admitted during 2015, and Entamoeba Histolytica was the most common isolated pathogen in the study42 (48\%) patients. followed by E.coli 15 cases (17.4\%), shigella, salmonella 7(8\%) and 4(4.7\%) respectively . The most vulnerable age was those below 2 years $(58 \%)$ and males were affected more than females (1.3:1), (37\%) were bottle fed. The majority had chlorinated tap water supply (82.6\%).
\end{abstract}

Key wards: bloody diarrhea/children/under 5/children

\section{Introduction}

Diarrhea is a preventable and treatable disease however it is still a major public health problem particularly in developing world It ranks as the third leading cause of both mortality and morbidity among infectious diseases, placing it above tuberculosis and malaria ${ }^{1}$. About $80 \%$ of deaths due to diarrhea occur in the first two years of life. The main cause of death from acute diarrhea is dehydration. Other important causes of death are dysentery, malnutrition and serious infections such as sepsis ${ }^{2}$. Bloody diarrhea in young children is usually a sign of invasive enteric infection that carries risk of serious morbidity and death. Noninfectious causes account for a very small proportion of episodes of bloody diarrhea ${ }^{3}$ About $10 \%$ of diarrheal episodes in children under 5 years of age have visible

\section{Corresponding auther:}

Maral F Thabit:

Institute of Medical Technology, Baghdad.

Email:maral.fthabit@yahoo.com blood in the stool and these account for about $15 \%$ of diarrhea-associated death in this age group worldwide ${ }^{4}$. Compared with the watery diarrhea, bloody diarrhea generally lasts longer, is associated with more complications, is more likely to adversely affect a child growth and has a higher case fatality rate ${ }^{(5,6,7)}$. There is also a synergism between bloody and persistent diarrhea accompanied by malnutrition; therefore the control of bloody diarrhea will prevent most of deaths attributed to malnutrition and persistent diarrhea ${ }^{(2,8,9)}$. According to WHO, in Iraq, the sanitary condition and general hygiene all over Iraq had been deteriorated during the last decade, particularly following the last war 2003 $(2,10)$. However, only a few studies have described the epidemiology of bloody diarrhea among this age group.

\section{Aim of Study}

1. To identify the proportion of infective bloody diarrhea cases and their different etiological factors out of total number of gastro-enteritis.

2. To identify the predisposing factors of bloody diarrhea. 
3. To find the relation between the main infective etiological types of bloody diarrhea of the admitted patients and some sociodemographic factors of this study.

\section{Patients \& Method}

Study design: A Cross-sectional retrospective study.

Study period: it is carried out during the period extending from $1^{\text {st }}$ of January to $30^{\text {th }}$ of June 2016.

Study population: Children under 5 years.

Study place: Children welfare Teaching hospital/ Baghdad.

Study sample: (86) cases of bloody diarrhea out of (788) gastro-enteritis cases admitted in the above mentioned hospital during 2015.

\section{Data collection method:}

Patients with bloody diarrhea (three or more loose bowel motions / day with visible blood in stool) ${ }^{1}$. Those with surgical conditions were excluded from the study (e.g. volvulus, intussusception), reports were reviewed and data collected from the case files of the patients (name, age, gender, address, type of feeding, type of water supply, boiling of drinking water, the presence of domestic animals).
Confirmation of diagnosis: for each patient the following was done by the same qualified laboratory personnel by stool culture and slide agglutination test was also done but it was not possible to identify the causative agents in $18(21 \%)$, this could be due to infection with other organisms not routinely investigated in the stool samples or due to the lack of sensitivity of some laboratory procedures that used in this hospital or not present at all, this was similar to studies conducted in our country ${ }^{(10,11)}$.

\section{Statistical Analysis}

The data were analyzed statistically by using computerized SPSS system version (20).Descriptive statistics including observed frequencies and percentages. And Chi square test was used to assess the association between two categorical variables. P-value less than 0.05 was considered as a statistically significant, and value less than 0.01 was considered to be highly significant .

\section{Results}

Number of patients with bloody diarrhea was (86) from total number of patients of gastroenteritis (788) admitted to Children Welfare Teaching hospital during 2015 so the proportion of bloody diarrhea cases was $(10.9 \%)$.

Results of examination and stool culture (86) patients identified as follows

Table (1): Isolation rate of enteropathogenes in children with bloody diarrhea:-

\begin{tabular}{|l|l|}
\hline Enteropathogenes Isolated & $\begin{array}{l}\text { Number and percentages of } \\
\text { cases. }\end{array}$ \\
\hline E. histolytica & $42(48.8 \%)$ \\
\hline E. Coli & $15(17.5 \%)$ \\
\hline Shigella & $7(8 \%)$ \\
\hline Salmonella & $4(4.7 \%)$ \\
\hline No isolate & $18(21 \%)$ \\
\hline Total & $86(100 \%)$ \\
\hline
\end{tabular}

The proportion of causative agents in descending order, E. histolytica 42 (48.8\%), E. Coli 15 (17.5\%), Shigella $7(8 \%)$. Salmonella $4(4.76 \%), \& 18(21 \%)$ of cultures showed no isolates. 
Table (2): Age Distribution of the patients according to etiological agents:

\begin{tabular}{|c|c|c|c|c|}
\hline \multirow{2}{*}{ Age(month) } & \multicolumn{3}{|c|}{ Etiological agent } & \multirow{2}{*}{ Number of patients } \\
\hline & Bacterial & Amoebic & Unknown & \\
\hline $1-12$ & $4(18.1 \%)$ & $13(59 \%)$ & $5(22.7 \%)$ & $22(25.6 \%)$ \\
\hline $13-24$ & $9(32.2 \%)$ & $17(60.7 \%)$ & $2(7.1 \%)$ & $26(32.6 \%)$ \\
\hline $25-36$ & $4(40 \%)$ & $33(30 \%)$ & $3(30 \%)$ & $10(11.6 \%)$ \\
\hline $37-48$ & $7(46.6 \%)$ & $4(26.7 \%)$ & $4(26.7 \%)$ & $15(17.4 \%)$ \\
\hline $49-60$ & $2(18.1 \%)$ & $5(45.5 \%)$ & $4(36.4 \%)$ & $11(12.8 \%)$ \\
\hline ToTotal & 26 & 4242 & 18 & 86 \\
\hline
\end{tabular}

$$
\mathrm{X}^{2}=\mathbf{2 0 . 9 5}, \mathrm{P} \text { value }=\mathbf{0 . 0 0 1}
$$

The majority of bloody diarrhea cases $50(58.2 \%)$ found in those who were below 2 years. There is highly statistically significant difference $(\mathrm{p}$ value $<0.01)$ between different etiological agents and age group.

Table (3): Sex distribution of the patients according to the etiological agents :

\begin{tabular}{|l|l|l|l|l|}
\hline \multirow{2}{*}{$\begin{array}{l}\text { Sex of } \\
\text { child }\end{array}$} & \multicolumn{2}{|l|}{ Etiological agent } & \multirow{2}{*}{ N. No of Patients } \\
\cline { 2 - 5 } & Bacterial & Amoebic & Unknown & \\
\hline Male & $16(32 \%)$ & $23(46 \%)$ & $11(22 \%)$ & $5050(58.2 \%)$ \\
\hline Female & $10(27.8 \%)$ & $19(52.8 \%)$ & $7(19.4 \%)$ & $36(41.8 \%)$ \\
\hline Total & 26 & 42 & 18 & 86 \\
\hline
\end{tabular}

$\mathrm{X}^{2}=1.97, \mathrm{P}$ value $=\mathbf{0 . 0 4}$

Males were more affected $50(58.2 \%)$ than females 36(41.8\%) There is significant difference between total number of cases and gender of the patients $\mathrm{p}<0.05$.

Table (4): Distribution of the patients and their etiology according to the type of feeding

\begin{tabular}{|l|l|l|l|l|}
\hline \multirow{2}{*}{ Type of feeding } & \multicolumn{2}{|l|}{ Etiological agent } & Unknown & No. of patients \\
\cline { 2 - 5 } & Bacterial & Amoebic & $5(5(19.2 \%)$ & $26(30.2 \%)$ \\
\hline Breast & $12(46.1 \%)$ & $9(34.6 \%)$ & $6(6(18.7 \%)$ & $32(37.2 \%)$ \\
\hline Bottle & $6(18.7 \%)$ & $20(62.5 \%)$ & $3(3(23 \%)$ & $13(15.1 \%)$ \\
\hline Diet & $4(30.7 \%)$ & $6(46 \%)$ & $4(4(26.6 \%)$ & $15(17.5 \%)$ \\
\hline Mixed & $4(30.7 \%)$ & $746.6 \%)$ & 18 & 86 \\
\hline Total & 26 & 42 & & \\
\hline X2 X2 $=12.47, \mathrm{P}=0.002$. & & & \\
\hline
\end{tabular}


There are statistically significant differences ( $\mathrm{P}$ value $<0.05$ ). Between number of cases of bloody diarrhea and different types of feeding showed more patients admitted with bottle feeding $37.2 \%$.

Table (5): Distribution of the patients and their etiology according to the types of water supply:

\begin{tabular}{|l|l|l|l|l|}
\hline \multirow{2}{*}{ Water supply } & \multicolumn{2}{|l|}{ Etiological agent } & \multirow{2}{*}{ NO. of patients } \\
\cline { 2 - 5 } & Bacterial & Amoebic & Unknown & $71(82.6 \%)$ \\
\hline Tap water & $21(29.5 \%)$ & $36(50.8 \%)$ & $14(19.7 \%)$ & $15(17.4 \%)$ \\
\hline $\begin{array}{l}\text { Others like river, } \\
\text { irrigation, } \\
\text { canal, wells }\end{array}$ & $5(33.3 \%)$ & $6(40 \%)$ & $4(26.7 \%)$ & 86 \\
\hline $\begin{array}{l}\text { Total } \\
\text { X2 X2 }=24.7 ., \text { P value }=0.001\end{array}$ & 26 & 42 & 18 & \multirow{2}{*}{} \\
\hline
\end{tabular}

There is a highly significant $(\mathrm{P}$ value $<0.01$ ) relationship between total number of patients and different types of water supply. 71(82.6\%) of patients used tap water. There is also a relationship between different etiological factors and type of water supply. Tap water associated with more amoebic diarrhea36 (50.8\%) than bacterial 21(29.5\%).

Table (6): Distribution of the patients and their etiology according to the habit of boiling water:-

\begin{tabular}{|c|c|c|c|c|}
\hline \multirow{2}{*}{ Boiling of water } & \multicolumn{3}{|c|}{ Etiological agent } & \multirow{2}{*}{ NO. of patients } \\
\hline & Bacterial & Amoebic & Unknown & \\
\hline Yes & $7(46.7 \%)$ & $5(33.3 \%)$ & $3(20 \%)$ & $15(17.44 \%)$ \\
\hline No & $19(26.8 \%)$ & $37(52.1 \%)$ & $15(21.1 \%)$ & $71(82.56 \%)$ \\
\hline Total & 26 & 42 & 18 & 86 \\
\hline \multicolumn{5}{|c|}{$\begin{array}{l}\mathrm{X} 2 \mathrm{X} 2==5.6, \mathrm{P} \text { value }=0.001 \\
\text { There is a highly significant } \mathrm{P} \text { value }<(0.01) \text { relationship between total } \\
\text { nunumber of patients and habit of boiling water, showed more patients of bloody } \\
\text { bl diarrhea were using un boiled water } 71(82.5 \%) \text {. }\end{array}$} \\
\hline
\end{tabular}

\section{Discussion}

The study revealed that the number of cases of bloody diarrhea was (86) cases from (788) cases of total gastroenteritis admitted during 2015 , the percentage was $(10.9 \%)$ this result is similar to ${ }^{7}$ in Baghdad .

Entameoba histolytica_was the most common isolated pathogen as it was detected in stool sample of the patients. This finding was similar to that observed in studies conducted in Basrah by $(12,13,14)$ in Baghdad.

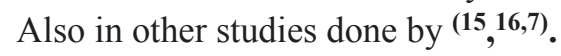

The opposite finding was reported in many studies in different countries which showed that shigella species were the most common agent associated with bloody diarrhea $(5,6,17,18,19)$ the reason for this difference could be explained by the fact that invasive amebiasis is an important public health problem and occur globally in endemic areas ${ }^{3}$. On the other hand, probably amebiasis is routinely over diagnosed and laboratory reports may be of little value, a study done by Walsh support that ${ }^{20}$.

Entameoba histolytica cyst was found in (38\%) of bacterial bloody diarrhea. This means that more than one pathogen may be isolated from patients with bloody diarrhea. This is in agreement with studies done by $\mathbf{( 2 1 , 1 6 )}^{\text {. }}$ 22 found that association of E. coli with Entameoba histolytica infection will enhance amebic virulence. 
It was not possible to identify the causative agent in 18 cases $(21 \%)$. This could be due to infection with other organisms not routinely investigated in the stool samples or due to the lack of sensitivity of some laboratory procedures, This is in agreement with other studies $\mathbf{( 1 0 , 6 , 1 8 ) .}$

The age of the most affected children was between (7-12 ) months. A similar result was also found by $(\mathbf{8 , 2 3 )}$ . Susceptibility of this age group to bloody diarrhea may be explained by many factors such as declining level of maternal immunity, introduction of solid food which may be contaminated by enteropathogens, together with introduction of foreign material to the mouth of these children as they have learned to crawl up and pick subjects in their hands by this age, which increases the risk of exposure to fecal pathogens ${ }^{(24,25)}$. Also most of the admitted cases were in this age group ,because of high worry of the families toward their children at this age group ${ }^{(2,10)}$.

Male sex was affected more than female with ratio

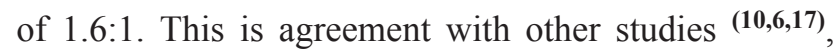
while the opposite found by 18 .

The significant difference in sex distribution was in those amebic dysentery, male to female ratio 2.2:1. This was also found by ${ }^{(25,26,27)}$ in Ethiopia .

A high percentage were bottle fed 32 (37\%) while breast fed is less $26(30 \%)$ and this strengthen protective value of breast milk against diarrhea, weather bloody or watery. Similar results were found by $(2,23,25,28)$

The majority of the patients included in the study had tap water supply $71(82.6 \%)$ while other sources is just 15 (17.4\%).However, even chlorination of water cannot kill amoebic cyst or some other enteropathogenes this was aided by some studies ${ }^{(\mathbf{1}, 10)}$, or it may be due to contamination of water system by ground water responsible for outbreak of amoebic dysentery ${ }^{29}$.

\section{Conclusions}

1. The proportion of infective bloody diarrhea out of total gastroenteritis cases was relatively low .

2. Entamoeba histolytica is one of the most frequent offending pathogen in patients with bloody diarrhea in our society.

3. Children below 2 years are the main affected group and male sex affected more than females .
4. Bottle feeding preference, non-boiling of drinking water make children more prone to have bloody diarrhea.

5. Tap water use was associated with cases of bloody diarrhea.

Source of Funding: Self-funding.

Ethical Consideration:Approval to conduct this study was obtained from concerned authorities (Children Wefare Hospital in Baghdad), as well as the name of the participants was kept hidden.

\section{Conflict of Interest: Nil}

\section{References}

1- Behrman RE, Kligman RM, Jenson HB ,(eds). Nelson text book pediatrics, 18th ed. Philadelphia, W.B. Saunders Company, 2007;1369.

2- Bartram J. New water forum will repeat old message. Bulletinn $\mathrm{f}$ the World Health Organization, 2003; $83(3): 158$.

3- WHO. Meeting of the Immunization Strategic Advisory Group of Experts, April 2009, conclusions and recommendations. Wkly Epidemiol Rec World Health Organization 2009; 84:220 - 236.

4- Victora CG, Huttly SRA, Fuchs SC, et al. international differences in clinical patterns of diarrheal deaths: a comparison of children from Brazil, Senegal, Bangladesh and India. J. diarrheal Dis. Resources 1993; 11:25-29.

5- Black RE, Brown KH, Becker S, et al. Longitudinal studies of infectious disease and physical growth of children in rural Bangladesh. Am J Epidemiology. 2000; 115:315-324.

6- Ronsmans C, Bennish ML, Wierzba T : Diagnosis and management of dysentery by community health workers. Lancet 1988; 2: 552-55.

7- Dhia H, Al-Ma'eeni A, Mustafa SA. Infectious bloody diarrhea in children 2 month - 5 years. Descriptive hospital Based Study; Facul Med Baghdad, 2011; 53: (2).

8- Henry FS. The epidemiological importance of dysentery in community. Rev. infectious diseases 2002;4: 3000-44.

9- Veinh H , Wain J , Chinh MT, et al. Treatment of bacillary dysentery in vitnamese children trop. Med. Hyy. 2000;94: 324-326. 
10- Basher H Al Mamory : Bloody Diarrhea in children under five years old in Babil teaching hospital, Clinical and epidemiological study. A thesis submitted to the Iraq Commission for Medical Specialization In Partial Fulfillment of the Requirement for the Degree of Fellowship of the Iraqi Commission for Medical Specialization In Pediatric, 2008.

11- Barwick RS, Levy DA, Craun GF, et al. Surveillance for waterborne disease outbreaksUnited states, 1997-1998. MMWR Morbid Mortal Wkly Rep 2000; 49:1-35

12- Edward S , AL-Muck J, AL-Ani W. Epidemiology of bloody diarrhea. Iraq.J.Comm. Med.2000; 13 (1): 6-10.

13- Mohammad HF. Comppylobacter jejuni Gastroentetitis In Children In Basrah. A thesis submitted to the Iraq Commission for Medical Specialization In Partial Fulfillment of the Requirement for the Degree of Fellowship of the Iraqi Commission for Medical Specialization In Pediatric , 2001.

14- Mahdi LK. Infantile diarrhea and type of feeding. A thesis submitted to the Saddam College of Medicine and the Committee of post-graduate studies of the University in partial fulfillment of the requiremens for the degree of Ph.D. in Microbiology, 1998.

15- Cunin P, Tedjouka E, German Y. An epidemic of bloody diarrhea, E.Coli O157 emerging in Cameron. Emerg. Infect. Dis. 1999; 5 (2): 285-_90

16- Lai_SW, Lin_HC, Lin_ CC, et al . Clinical analysis pf a dysentery outbreak in Taichung. Chung - Hua- kuo- Erh-Tsa- Chih.2000 Jan - Feb; 41(1):18- 21 .

17- Huilans S, zhen, LG, MATHAN Nm, etal. Etiology of acute diarrheoa among children in developing countries:amulticenter study in five countries. Bull world health organization 1991;69:549-55

18- Townes JM, Quick R, Gonzales OY, et al. etiology of bloody diarrhea in Bolivian children implication for empiric therapy. J. infectious disease 1997;175:1527-230.
19- Khalil_khan, SR. MAZHAR_, Et al. occurrence and susceptibility of shigella species in stool of hospitalized children with bloody diarrhea in Pakistan. AM-J-TROPMED-hug 1998; 58(6).

20- Walsh JA. Problems in recognition and diagnosis of amebiasis. Rev. Infect. Dis.

21- Masoumi_JP; Anwar_ MS; Bkhari_SR. Clinical features of infantile diarrhea associated with single or multiple enteric pathogens. JPMA- J-Pak-MedAssoc. 1995 Oct; 45 (10): 266-9 .

22- Sinha - P, Naik - S, Ayyagari - A, et al. The effect of in vitro bacterial association on virulence of Entameba histolytica. Indian - J - Med - Res. 1997 Jun; $105: 266-70$.

23- Al-Kubiassy- Waqar, Amer Al-B. Epidemiological study of bloody diarrhea among children in Baghdad, Iraq ,2015; 3-4.

24- Khan MU , Chandra Roy N , Islam MU, et al . Fourteen years of Shigellosis in Dhaka: An epidemiological analysis. Int. J. Epidem. 1985; 14:607 - 13 .

25- Ahmed - F , Clemens - JD, Rao - MR, et al . Epidemiology of shigellosis among children exposed to cases of shigella dysentery: a multivariate assessment. Am - J - Trop - Med Hed - Hyg. 1997 Mar; 56 (3) : 258 - 64.

26- Kessler BH , Klish WJ . Entameba histolytica. In : Frank A. Oski; Ralph D. Fegin. (eds). Principles and Practice of Pediatrics, 2nd ed. 1994; 62: 1386 87.

27- Teklemariam - S, Getaneh - T , Bekele - F. Environmental determinants of diarrheal morbidity in under - five children, Keffa - Sheka zone. South West Ethipoia - Med - J . 2000 Jan; 38(1) :27-34.

28- Al-Rbaii ES .Clinico-epidemiological study of bloody diarrhea in children below 5 years.ICMS dissertation,Community Medicine.University of Al-Muxtasnsiriyah. 2001.

29- Ashcraft KW. Rectal Prolapse. In : Ashcraft, K.W.; Murphy, J.P.; Sharp. R.J. (eds) Pediatric Surgery, 3td ed. Pheladelphie, W.B. Saunders Company 2000; 38: 512,513 . 